\title{
Research on Problems and Strategies of University Accountants' Continuing Education
}

\author{
Li LI \\ Financial Service Department, Beihua University, Jilin 132013, China.
}

\begin{abstract}
KEYWORD: universities; accountants; continuing education
\end{abstract}
\begin{abstract}
With higher education structural reform deeply, the socialization of logistic guarantee and the Market-oriented of economic behaviors, the finance services of universities are faced with unprecedented challenges. Along with the development of accounting reform, the related theories become richer, the relevant legislations are reaching perfection, the accounting treatment will be changing rapidly and the requirement for accountants is higher and higher. In order to break the invisible barrier between theory and practice, pre-service and in-service and directly connects accounting education with the reality. In this paper, the propose is to set up the correct modern continuing educational philosophy; enrich training details; enlarging the number of qualified teachers; ensure the effective educational pattern and establishing the long-acting mechanism.
\end{abstract}

\section{GENERAL INSTRUCTIONS}

In recent years, due to the adjustment of national policy, the scale of college enrollment has expanded year after year, the amount of funds invested in colleges and universities is also growing, all aspects of the work of colleges and universities have undergone tremendous changes. This leapforward development of universities, especially the rapid increase in investment in education, making the accounting work has also occurred in the quality and quantity changes. On the one hand, colleges and universities face more and more economic activities. As long as the management of the school on teaching and research aspects of financial problems, and now many colleges and universities have school-run enterprises, logistics groups, school hospitals, secondary schools, publishing houses and other secondary units or affiliated units. Some of these units to implement the accounting system, and some implementation of enterprise accounting system, the need to guide the financial sector of colleges and universities, supervision or dispatch of accounting personnel, the number and type of business are rising rapidly. On the other hand, the income channels of colleges and universities have increased, and the amount of funds has undergone enormous changes. In the past, colleges and universities mainly relied on financial allocations. Now, the situation of raising funds through various channels has basically taken shape. Apart from financial allocations, there are tuition fees, accommodation fees, donations, cooperative schools, affiliated units, loans and so on. Correspondence with this, college spending has become more complex.

In addition to the distinction between personnel expenditure and daily public expenditure, but also distinguish between special expenditure and non-earmarked expenditure, according to the use of distinction between teaching expenditure, scientific research expenditure, logistics expenditure, student spending, operating expenses, etc., objectively make financial accounting tasks Getting heavier and heavier. Accounting has its own development and changes, accounting is with the economic development and development, economic development, accounting work also will continue to change, with the deepening of the accounting reform, accounting-related theory more Rich, the relevant laws and regulations more perfect, accounting treatment is also their quality. At present, the accounting work is no longer a simple accounting for the past, but to raise funds from the use of a full range of management. Accounting forms also from the past manual operation for the development of today's computerized accounting management. Computer operation has been fully universal, all kinds of accounting, management software, upgrading. The quality of accounting personnel directly affects the quality of accounting information. At the same time, with the continuous development of colleges and universities, the new economic things are emerging, these are college accountants put forward higher requirements, need not only understand the business, accounting, but also skilled in computer, good management, Accounting staff, therefore, with highquality team is the financial needs of the school development. 


\section{AN INVESTIGATION ON THE CURRENT SITUATION OF CONTINUING EDUCATION OF ACCOUNTANTS IN COLLEGES AND UNIVERSITIES}

It is understood that the continuing education of college accountants are mainly two ways: First, the training institutions to send teachers to teach materials according to training; Second, the financial departments of colleges and universities to hire their own experts lectures. In order to accurately grasp the present situation of continuing education of accountants in colleges and universities, and objectively analyze the existing problems and causes, the author carries out a questionnaire survey on the continuing education of accounting personnel in some colleges and universities. A total of 300 questionnaires were sent out, 245 of which were returned, of which 241 were valid questionnaires, accounting for more than $80 \%$ of the total. The survey covers more than 10 colleges and universities, including Sichuan University, Southwest Jiaotong University, Chongqing University, Southwest University and Chang'an University, including general colleges and universities, 211 universities and 985 colleges and universities. The survives are all in the accounting profession. The questionnaire is divided into two parts, a total of fifteen questions, the front part of a total of five questions, mainly the basic situation of the respondents, including gender, age, education, title, engaged in financial work; , Mainly on the continuing education of college accountants the status quo and views were investigated.

The survey found that college accountants for the current continuing education in all aspects of recognition is not high. On the content of education, as high as $48.5 \%$ of the people that "general", that "poor" also 33.5\%; that the current teaching form "better" and "very good" accounting staff of $2.6 \%$; And the quality of continuing education teachers is only 10.3 . There are $54.6 \%$ of accounting personnel in colleges and universities believe that the current mode of continuing education assessment needs to be improved. Through informal interviews, it is found that the demand for continuing education of college accountants is still very high. It is generally hoped that the continuing education will be strengthened, more training opportunities and time will be gained, and more content, Can have more autonomy options.

From the survey results, the current form of continuing education of college accountants, the content is relatively simple, teaching methods to the traditional classroom-based assessment to open-book examination based. The main channel for university accountants to participate in continuing education is to participate in training courses (up to 85\%), while the other way through the title examination, academic training, meeting and exchange is only $15 \%$. University accounting staff generally believe that the opportunities for continuing education is not much, and high-quality, high-level opportunities for further education less. Continuing education is dominated by state regulations (60\%), but accountants are less concerned with direct knowledge (5\%) of their work. Teaching methods have changed, began to hire expert lectures, using case teaching and interactive hot spots and other means, but still the traditional classroom teaching (75\%), the teacher scripted, students are not interested. Examination is a mere formality, the proportion of open-book examination up to $85 \%$.

\section{THE PROBLEMS OF CONTINUING EDUCATION OF ACCOUNTANTS IN COLLEGES AND UNIVERSITIES}

In recent years, with the continuous reform of our country's education system, the deepening of accounting reform, the increasingly heavy financial work in colleges and universities, accounting practitioners are also increasing. Increasingly large accounting team in the proportion of young accounting practitioners are also increasing year by year. Some of the older accounting staff with low academic qualifications, although experienced, but the relative lack of theory, computer operation is not enough skilled, can not handy to use a variety of financial software; and newly recruited accountants for school teaching to enterprise accounting, Finance is still relatively unfamiliar, the relative lack of experience, colleges and universities continue to educate a long way to go. The continuing education of accounting personnel has broken the barrier of obstacle in theory and practice, pre-employment and post-employment, and directly communicated the connection between accounting education and practice. The professional skills of vocational judgment, interpersonal skills, project management skills and communication skills can make the accounting practitioners of colleges and universities adapt to the needs of the market and the development of 
the school as soon as possible through continuing education of the accounting practitioners in colleges and universities.

However, due to the late start of China's continuing education, college accountants to start a later education, accounting personnel colleges and universities by the respective financial sector management, is basically the same with other institutions accounting staff training, there is no specific specifically for colleges and universities Accounting staff to develop continuing education planning, through the survey found that there are still many difficulties and problems in continuing education: accounting staff to receive continuing education, not only in the practical needs of accounting work, but also the relevant provisions of the accounting regulations, is the long-term development of colleges and universities The need. The development of the school is inseparable from the protection of funds, and funds to raise, arrange, use the accounting staff have the hard work of colleges and universities. The development of colleges and universities is dynamic. In order to develop better, it is necessary for accounting personnel to provide accurate and accurate accounting information to provide scientific basis for management decision-making, and accounting personnel are also directly involved in economic business negotiation and contract documents validation. These are the accountants before the entry of the school to learn the expertise is not competent. Only through continuing education can we keep pace with the times and meet the needs of school development. But at present, not only the leadership of our colleges and universities at all levels do not attach importance to a considerable number of accounting personnel on their own understanding of the existence of continuing education gap. The questionnaire shows that $25 \%$ of the college accounting staff that continue education is not important, $30 \%$ of the staff that the general, that is very important only $10 \%$.

The focus of the work of colleges and universities tend to teaching, scientific research, financial services as a logistical support for teaching and research. In charge of the financial work is not enough understanding of the accounting staff to continue education is also not enough. Accounting staff continue education is a long process, the effect is difficult to immediate, many university leaders that it can not directly benefit the school that the accounting staff to participate in continuing education will delay the time, affecting the normal work, so do not want the accounting Personnel continue to invest too much education and time. Data show that unit leaders are very supportive of the unit accounting staff to receive continuing education accounted for only 35\%, most of the unit leaders do not support the accounting staff to receive continuing education. Some teachers also misunderstand the continuing education of accountants. Such as a university finance department in the weekly week fixed a half-day business learning, not to open business, some teachers and even the leadership of the financial sector that do not work half a day, great views. Some colleges and universities financial staff also regard continuing education as a form, that the purpose of participating in continuing education is to pass the annual inspection, making the accounting staff continue to become an annual routine of education.

According to the author's observation and understanding, in continuing education, can always adhere to the study until the expiry of only a small part of the training staff, some of the accounting staff is only the application and participate in the final exam, the lack of learning initiative and enthusiasm. However, with the rapid development of colleges and universities, the scale and capital of the university are expanding, the sources of funds are increasingly diversified, the coexistence of various forms of running schools, cooperation with various units outside the school has been increasing, accounting requirements continue to increase, accounting means Accounting, and reimbursement, and only an effective continuing education, only one can improve the quality of accounting teams, and enhance its adaptability in the complex economic environment and the financial environment, Resilience.

The rigidity of employment mechanism in colleges and universities, the incentive incentive system is not smooth. Seventy-five percent of the respondents said that their pay was not related to the situation of continuing education. Colleges and universities are institutions, accounting practitioners pay and their ability to have little relationship, only to work with the number of years, titles, jobs linked. And the salary level between the low title and the high title has little difference and has great stability, can not form an effective salary incentive. According to the relevant personnel system, the school is easy to school difficult, dry and less a sample, and accounting staff mobility is poor, rising platform is limited, it is easy to cause staff to meet the status quo, unwilling 
to make progress. Even if the school arrangements for the accounting profession training, it is also to sign a name and then sit there "in Cao Ying heart in the Han", not to mention their own subjective to learn new knowledge.

\section{HOW TO SOLVE THE PROBLEMS OF CONTINUING EDUCATION OF ACCOUNTANTS IN COLLEGES AND UNIVERSITIES}

Establishing the correct concept of modern continuing education is the prerequisite for the effective continual education of accountants. Successful implementation of continuing education requires a change of concept - the control of learning is given to the learner and the learner centered learning mechanism is established. This requires the following aspects of the joint efforts. Financial departments should strengthen macro-control and guidance, formulate relevant implementation plans and management systems, strengthen supervision and guidance on the access to continuing education and training institutions, departmental classes, training content, training of teachers, training conditions, training fees and other links; Full investigation and earnestly master the area of accounting practitioners overall situation, according to the industry, job titles, education and other sub-levels to develop long-term training program; to focus on continuing education teacher team, make full use of university personnel resources, Into the system, regular training system and student evaluation system.

Training institutions at all levels should be in strict accordance with the financial sector to develop the implementation of the program and management system requirements to strengthen and improve their own building, fully aware of the importance of continuing education for accounting staff, continuing education and training for each responsibility to employ qualified teachers, , Assessment, making each of the continuing education to achieve the desired results. Only in this way, training institutions to achieve long-term development, to achieve the purpose of profit.

At present, university corruption is not a new topic, corruption must involve power transactions, improve the system, improve the quality of personnel will help to solve these problems, including the financial system and improve the overall quality of the accounting staff is very important aspect. The continuing education of the accounting personnel is an important guarantee for the healthy development of colleges and universities. The leaders of the university should attach great importance to the continuing education work of the accounting personnel. They should fully understand, understand and support the continuing education of accounting personnel, put it into the skill level of the accounting staff, Prevent the accounting risk and improve the financial management level of the university, so that it gradually changes from the accounting type accounting to the management accounting. In the era of knowledge economy, college financial work is no longer accountable so simple, the school finance department to manage a billion dollars a year of huge funds, from fund raising to use, need to use good network technology, financial software support and other conditions.

\section{CONCLUSION}

1. The connotation and characteristics of continuing education of accountants in colleges and universities are clarified. Continuing education of accountants in colleges and universities refers to a kind of on-the-job training based on knowledge updating, which is carried out by the person who is engaged in accounting work and holds qualification certificate of accounting personnel in a certain period of time in accordance with relevant regulations of the state. At the same time, it points out that it has the features of coercion and spontaneity, timeliness and long - term, in service and hierarchical, practicability and service.

2. The status quo of the continuing education of accountants in colleges and universities is investigated. We find that there is not enough attention paid to the continuing education of accountants in colleges and universities, the lack of pertinence and hierarchy, the low quality of teachers, the unavailability of education channels and the single form of accounting education.

3. Through the analysis of the existing problems of the continuing education of accounting personnel in colleges and universities, the corresponding countermeasures are put forward: the financial management department and training institutions, the leaders of colleges and universities and accounting practitioners should establish the correct modern continuing education concept; 
Training content; to improve the quality of continuing education teachers; establish effective continuing education model; the establishment of continuing education and long-term mechanism.

\section{REFERENCES}

Ren Yi, Liu Xiaohai, Liao listen based on C/S and B/S hybrid architecture with examples of analysis Computer Engineering and Applications 2014 (16): 159-160

Qi Yan. Japan's CPA follow-up education system. Chinese certified public accountants, 2013.8

Liu Zhisheng, Accounting Continuing Education, Sichuan Accounting, 2011.1

Zhang Chuanhai. On the continuing education of accounting staff to explore a number of issues. Theory and Practice of Finance and Economics, 2006.12

Internet companies and their impact on financial accounting. Accounting research, 2009.1

Sun Liyan Several Attempts to Improve the Teaching Quality of Continuing Education of Accounting Personnel Beijing Finance and Accounting, 2013.5

Innovations in the continuing education model for accountants at present. Adult Education, 2011.9

Journal of Adult Education College of Hebei University of Technology, 2008.1 (in Chinese). Journal of Adult Education College of Hebei University of Technology.

Gu De-xue.Study on Learning Society and Problems in China.Journal of Adult Education College, Hebei University of Technology, 2013.3

A Study on the Further Education of Accountants in Colleges and Universities. Accounting Communication (General), 2013.1 